\title{
The Jesuits and Slavery
}

\author{
Adam Rothman \\ Georgetown University, Washington, DC, USA \\ ar44@georgetown.edu
}

\begin{abstract}
Despite extensive historiography, most people are not aware that the Society of Jesus owned people. Even Jesuit historiography sometimes neglects that complicated history. The historiography of slavery, however, has long tapped into Jesuit sources and produced a rich scholarship on Jesuit debates over slavery and their slaveholding practices across the Americas. This essay places Jesuit slaveholding in the context of the Jesuits' global history and argues that genealogical research and calls for reconciliation provide an opportunity to renew and reorient scholarship towards the social history of the people owned by the Jesuits.
\end{abstract}

\section{Keywords}

slavery - historiography - reconciliation - archives - Americas - United States - Jesuit slaveowners

"We have greatly sinned," declared Timothy Kesicki, S.J., to a packed audience in Georgetown University's Gaston Hall, on April 18, 2017..$^{1}$ The president of the Jesuit Conference of Canada and the United States, Fr. Kesicki apologized for the Society's complicity in the history of slavery and for the specific act of the notorious sale of roughly three hundred people owned by the Maryland Jesuits in 1838 . He was joined on the stage by Georgetown's President John J. DeGioia,

1 "Homily of Fr. Timothy Kesicki, SJ, at Georgetown University's Liturgy of Remembrance, Contrition and Hope," Jesuits.org, https://web.archive.org/web/20171010144011/https://jesuits. org/news-detail?TN=NEWS-20170417100613 (accessed September 24, 2020). Gaston Hall is named after Georgetown's first student, William Gaston, a slaveowner. 


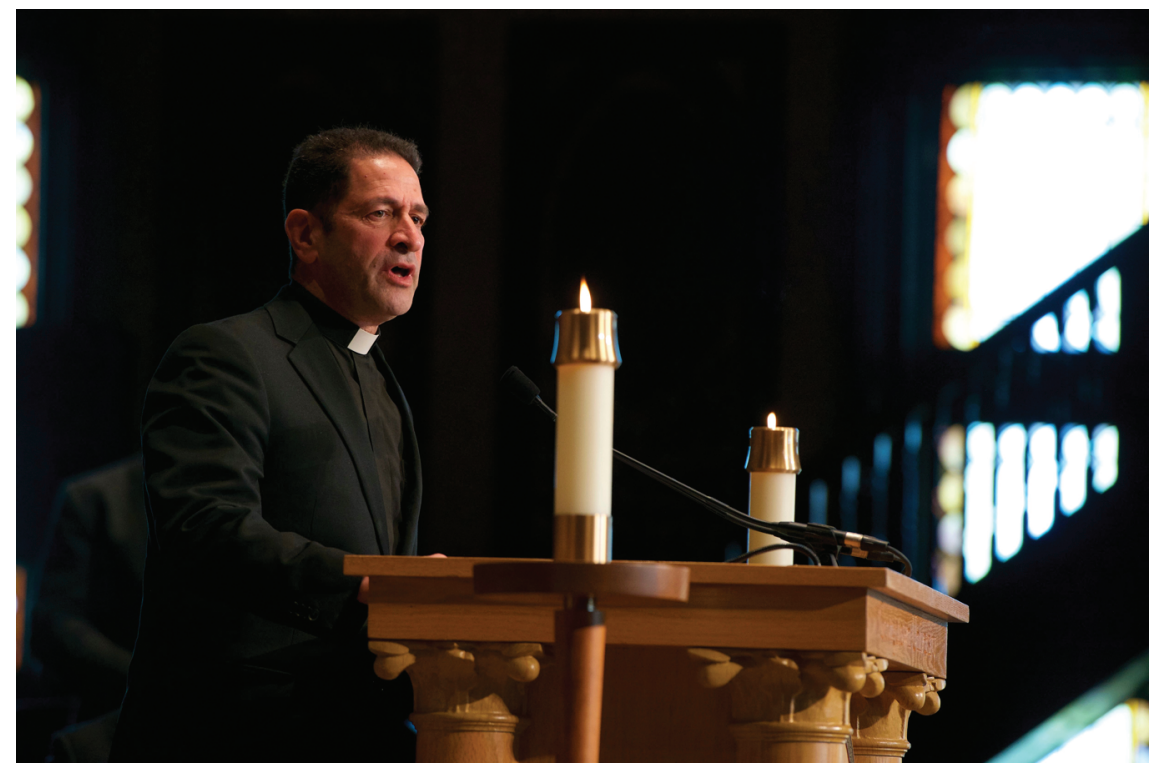

FIGURE 1.1 Timothy Kesicki, S.J., apologizes for the Jesuits' sin of owning and selling people. Gaston Hall, Georgetown University, April 18, 2017. PHOTOGRAPH COURTESY OF GEORGETOWN UNIVERSITY

and members of the "GU272" descendant community, the living descendants of the people sold by the Maryland Jesuits in 1838 . Together, they participated in a ceremony intended to recall the history of slavery in the past and advance the prospect of reconciliation in the present. It was a powerful moment I had the privilege to witness in person.

The event arose from two years of intense wrestling with the legacies of slavery at Georgetown. At the start of the 2015-16 academic year, President DeGioia launched a Working Group for Slavery, Memory, and Reconciliation to study Georgetown's historical connections to slavery and to make recommendations to him about how the school could acknowledge this aspect of its past. President DeGioia was responding not only to the reopening of a newly renovated building on campus named after Thomas Mulledy, S.J. (1794-186o), a former president of Georgetown (1829-38, 1845-48) who had been the chief architect of the 1838 sale, but also to broader social anguish and strife sparked by the shooting of Michael Brown (1996-2014) in Ferguson, Missouri, and the massacre at Emanuel African Methodist Episcopal Church in Charleston, South Carolina. ${ }^{2}$ What happened next at Georgetown is probably well known

2 John J. DeGioia, “A Message Regarding Mulledy Hall," September 24, 2015, https://president. georgetown.edu/mulledy-hall/\# (accessed June 3, 2020). 
to readers of this journal. After months of research and discussion on campus, revelations of the identification of living descendants of the people owned and sold by the Maryland Jesuits hit the front page of the New York Times, and a local story became national, and even international news. ${ }^{3}$ History had come to life.

There is much to say about these extraordinary events, but what I want to emphasize here is the relationship between scholarship and public knowledge. Most people did not know the history. Despite the existence of substantial scholarship on the Jesuits and slavery, the mere fact that the Maryland Jesuits owned and sold people came as a surprise and a shock to many in the Georgetown community and the broader public. That is one reason that the Working Group launched the Georgetown Slavery Archive (slaveryarchive.georgetown.edu) to make original archival materials documenting this history more accessible. It is also why the Working Group, in its report, recommended a vigorous program of education to make this history better known beyond the small circle of specialists. ${ }^{4}$

The other side of this coin is that scholars should respond to public interest in the history of the Jesuits and slavery by committing to a research agenda that builds on extant scholarship and sheds new light on the subject. As the essays in this volume show, there is still much to learn. Integrating Jesuit history with the history of slavery melds two venerable, rich, and complex historiographies, strengthening and deepening both areas of inquiry. Each challenges the other. Jesuit history must take on the challenge of deeply considering the experiences and perspectives of those who endured bondage at the hands of Jesuits, while the history of slavery, especially American slavery, would be well served by embracing the global breadth of Jesuit history. The voluminous archives of Jesuit activities around the world in the age of slavery presents an unparalleled opportunity to study one of the core ethical and historical problems of globalization and modernity.

The Jesuit entanglement with slavery still does not always get the attention it deserves, as two recent books by distinguished historians illustrate. John O'Malley's The Jesuits, a brisk and sweeping survey of Jesuit history, is nearly silent on the topic, while John McGreevy's American Jesuits and the World

3 Rachel Swarns, "Georgetown Confronts Its Role in the Nation's Slave Trade," New York Times, April 16, 2016, A.1.

4 See Report of the Working Group on Slavery, Memory, and Reconciliation to the President of Georgetown University (Washington, DC, 2016), 38-39, http://slavery.georgetown.edu/history/ working-group/report/ (accessed June 2, 2020). The Working Group was chaired by David Collins, S.J. 
devotes half a sentence to slaveowning by the Maryland Jesuits. ${ }^{5}$ Luckily, many scholars have tackled the Jesuit entanglement with slavery from a variety of angles, such as the early Jesuit debates over the legality of the slave trade and the Jesuits' management of enslaved labor in diverse economies across the Americas. ${ }^{6}$ Slaveholding by the Maryland Jesuits, and the story of the 1838 sale, would have come as no surprise to anybody familiar with the trailblazing research of R. Emmett Curran in the 1980s. ${ }^{7}$ One can find references to Jesuit encounters with slavery scattered throughout the Journal of Jesuit Studies, but this is the first issue of this journal devoted to the subject. ${ }^{8}$

The historical contours of the Jesuit entanglement with slavery follow the Society's global history from its earliest days through the era of abolition and emancipation in the nineteenth century, with the pivotal interruption of suppression. The Jesuits launched into a world in which slavery was not only rife but poised for remorseless expansion and intensification in the Atlantic littoral. As the Jesuits themselves began to employ slave labor, they developed a body of thought rooted in older ideas about who could be legitimately enslaved and why, and how slaves should be treated. From the sixteenth to the eighteenth centuries, the Jesuits were pioneers of what historian Robin Blackburn has called a "baroque" form of slavery affiliated with the "alternative modernity" of the Counter-Reformation: "an ancient and traditional form of domination transformed and thrown forward."

5 John W. O'Malley, The Jesuits: A History from Ignatius to the Present (Lanham, MD: Rowman \& Littlefield, 2014); John T. McGreevy, American Jesuits and the World: How an Embattled Religious Order Made Modern Catholicism Global (Princeton, NJ: Princeton University Press, 2016), 58.

6 David Brion Davis called attention to Jesuit debates over slavery in the sixteenth and seventeenth centuries in The Problem of Slavery in Western Culture (New York: Oxford University Press, 1966), 190-95. Models of the analysis of Jesuit slaveholding include Nicholas P. Cushner, Lords of the Land: Sugar, Wine, and Jesuit Estates of Coastal Peru, 1600-1767 (Albany, NY: State University of New York Press, 1980); Herman W. Konrad, A Jesuit Hacienda in Colonial Mexico, Santa Lucía, 1576-1767 (Stanford, CA: Stanford University Press, 1980); Stuart B. Schwartz, Sugar Plantations in the Formation of Brazilian Society: Bahia, 1550-1835 (Cambridge: Cambridge University Press, 1985).

7 See especially Robert Emmett Curran. "Splendid Poverty': Jesuit Slaveholding in Maryland, 1805-1838," in Catholics in the Old South: Essays on Church and Culture, ed. Jon L. Wakelyn and Randall M. Miller (Macon, GA: Mercer University Press, 1983), 125-46. See also Thomas Murphy, Jesuit Slaveholding in Maryland, 1717-1838 (New York: Routledge, 2001).

8 Ronnie Po-Chia Hsia, "Jesuit Foreign Missions: A Historiographical Essay," Journal of Jesuit Studies 1, no. 1 (2014): 47-65, https://doi.org/10.1163/22141332-0o101004; Emanuele Colombo, "Infidels at Home': Jesuits and Muslim Slaves in Seventeenth-Century Naples and Spain," Journal of Jesuit Studies 1, no. 2 (2014): 192-211, https://doi.org/10.1163/22141332-00102003; Barbara Ganson, "Antonio Ruiz de Montoya, Apostle of the Guaraní," Journal of Jesuit Studies 3, no. 2 (2016): 197210, https://doi.org/10.1163/22141332-00302002 (all JJS articles accessed June 13, 2020).

9 Robin Blackburn, The Making of New World Slavery: From the Baroque to the Modern, 1492-1800 (New York: Verso, 1997), quotations on 20, 22. 
The Jesuits ran into slavery at home and abroad. Substantial numbers of enslaved people lived in the cosmopolitan European port cities like Lisbon, Seville, and Rome where the Jesuits established themselves. The slave population was diverse, including Muslims and moriscos (Muslims who converted to Christianity and their descendants), North Africans and sub-Saharan Africans, and indios (indigenous people) trafficked from the Americas and Asia. In his extraordinary study of Portuguese involvement in the Asian slave trade, Lúcio de Sousa even found numerous instances of Japanese people held as slaves in Lisbon in the late sixteenth century. ${ }^{10}$ Enslaved people in Europe were a captive audience for evangelization. Emanuele Colombo has written about the Jesuit apostolate to Muslim slaves in Naples and Spain in the seventeenth century. To allay the fears of owners, conversion did not confer freedom. ${ }^{11}$ It would not be surprising to find enslaved people ministered to by Jesuits and working at Jesuit colleges and schools in southern Europe from the earliest days of the Society.

But it was overseas that the Jesuits wrestled with the realities of slavery most intensely, debating its propriety while reaping its profits. Enslavement could be an obstacle to evangelization by alienating non-Christians, or a means to achieve it by integrating them into the Catholic world and using their labor to underpin the Jesuits' religious economy. The Jesuit contribution to the debate over slavery in the Atlantic world is well known among scholars. Jesuits criticized the wanton enslavement of indigenous people in the Americas while leaving room for the enslavement of indigenous people in "just" wars waged to subdue resistance, and in notable instances Jesuits sought to protect indigenous communities in the Americas from the predation of slavers, as in the case of the Guaraní in what is today Paraguay, Argentina, and Brazil. Yet at the same time, Jesuits came to justify and participate in the Atlantic slave trade that carried ten million captive Africans to the Americas, and they worked thousands of African and African-descended enslaved people on their own haciendas and plantations. ${ }^{12}$

10 Lúcio de Sousa, The Portuguese Slave Trade in Early Modern Japan: Merchants, Jesuits and Japanese, Chinese, and Korean slaves (Leiden: Brill, 2019). See also Nancy van Deusen, Global Indios: The Indigenous Struggle for Justice in Sixteenth-Century Spain (Durham, NC: Duke University Press, 2015).

11 Colombo, "Infidels at Home."

12 On the Jesuits' attitudes towards the enslavement of indigenous people in the Americas, see, for example, Robert H. Jackson, Frontiers of Evangelization: Indians in the Sierra Gorda and Chiquitos Missions (Norman, OK: University of Oklahoma Press, 2017); Anne B. McGinness, "The Historiography of the Jesuits in Brazil Prior to the Suppression," Jesuit Historiography Online, ed. Robert A. Maryks (2018), http://dx.doi.org/10.1163/2468-7723_jho_COM_209645 
Jesuit justification and participation in the Atlantic slaving complex emerged from their involvement in Portuguese linkages between West and West-Central Africa and Brazil. Important intellectual contributions were made by Jesuits with experience in Atlantic Africa in the sixteenth and early seventeenth centuries, particularly Baltazar Barreira (1531-1612), whose career took him to Angola, Sierra Leone, and Cape Verde. Fending off doubts about the legitimacy of purchasing captive Africans, Barreira argued that slaving was a customary African practice and that it was impossible for Portuguese buyers to determine who had been enslaved justly or unjustly because neither the sellers nor the slaves could be trusted to tell the truth. Sellers would always claim their captives had been justly enslaved, while slaves would always claim the opposite. Better not to ask at all. Moreover, claimed Barreira, the Portuguese crown was entitled to slaves as "compensation" for all the wrongs Africans had done to the Portuguese. Barreira's arguments circulated widely and were persuasive. ${ }^{13}$

A growing historiography reveals that the problem of slavery was not just an Atlantic one. The Jesuits immersed themselves in slaving nodes and networks across the Indian Ocean and in the Pacific world. In a 2004 article, Thomas Nelson called attention to Jesuit debates over Portuguese involvement in slavery and human trafficking in Japan in the late sixteenth and early seventeenth centuries. Portugal's King Sebastian I (1554-78, r.1557-78) banned Portuguese merchants from buying slaves in Japan in 1570, but the trade persisted, inciting criticism from the powerful Japanese daimyo Toyotomi Hideyoshi (1536-98). In contrast to Barreira in Atlantic Africa, in 1598 the Jesuits in Japan came to condemn Portuguese merchants' buying of slaves there and called for the release of all Japanese slaves in Portugal's realms. ${ }^{14}$ More recently, though, Lúcio de Sousa has demonstrated that the Jesuits were complicit in the Portuguese slave trade from Japan from the 156 os to 1598 ; Jesuit priests supplied "ballots" for Portuguese slavers legitimating their purchases. ${ }^{15}$

(accessed June 2, 2020); H. Henrietta Stockel, Salvation through Slavery: Chiricahua Apaches and Priests on the Spanish Colonial Frontier (Albuquerque: University of New Mexico Press, 2004). See Ganson, "Antonio Ruiz de Montoya" for an account of one Jesuit's stand against the enslavement of the Guaraní.

13 The evolution of Jesuit arguments in favor of the enslavement of Africans is summarized well in Luiz Felipe de Alencastro, "Portuguese Missionaries and Early Modern Antislavery and Proslavery Thought," in Slavery and Antislavery in Spain's Atlantic Empire, ed. Josep M. Fradera and Christopher Schmidt-Nowara (New York: Berghahn Books, 2013), 43-73. On Barreira's defense of the slave trade, see P. E. H. Hair, "Heretics, Slaves and Witches: As Seen by Guinea Jesuits c. 1610," Journal of Religion in Africa 28, no. 2 (1998): 131-44 ("compensation" on 136).

14 Thomas Nelson, "Slavery in Medieval Japan," Monumenta Nipponica 59, no. 4 (2004): 463-92.

15 Sousa, Portuguese Slave Trade in Early Modern Japan, 277-85. 
In the Americas, Jesuits not only justified (African) slavery on an ideological level; they became major slaveowners. Canvassing the scholarship in his essay in this issue, Andrew Dial estimates that the Society of Jesus held more than twenty thousand people in bondage from Quebec to Quito by the mid-eighteenth century, with more than half of them in Brazil and Peru. Jesuit slaveholding, as John Tutino's essay on New Spain in this issue suggests, should not be seen as exceptional but as embedded in the diverse local, regional, and globally connected economies that the Jesuits operated in throughout the colonial world. Enslaved people worked on Jesuit sugar plantations, cattle ranches, tobacco farms and vineyards, urban colegios, and as domestic servants. Their arduous work was as varied as the early modern economies of the Americas. Slavery supplied profits and labor that sustained Jesuit schools, churches, and missions. In their own practices, the Jesuits modeled a Catholic ideal of slavery, but as Dial's essay shows, that model did not preclude ghastly violence.

The fact that the Jesuits wrote more and kept better records than many other slaveowners has been a great boon for historians of slavery and slave life even as the limits of the records highlight the weight of power upon the archives. ${ }^{16}$ Jesuit records have shed light on labor relations, demographic patterns, ethno-national identities, and the family lives of enslaved people. They also shed light on the Jesuits' Catholicizing efforts and enslaved people's responses to them. Alonso de Sandoval $(1576-1652)$ is a central figure in this drama. His efforts to proselytize among the Africans arriving by the thousands in Cartagena de Indias in the early seventeenth century, and his landmark treatise De instauranda Aethiopum salute (1627) justifying his efforts, have garnered attention from scholars for decades. ${ }^{17}$ Yet since the vast Jesuit archive of slavery was written by Jesuits for their own purposes, what enslaved people thought about all of this is much more difficult to discern. Nevertheless, as Alida Metcalf's study of the millenarian movement of Africans at Santidade

16 Michel-Rolph Trouillot, Silencing the Past: Power and the Production of History (Boston: Beacon Press, 1995).

17 Alonso de Sandoval, Natvraleza, policia sagrada i profana, costvmbres i ritos, disciplina $i$ catechismo evangelico de todos etiopes, por el p. Alonso, de Sandoval (Seville: Francisco de Lira, 1627). For a translation of key selections into English, see Nicole von Germeten, ed. and trans., Treatise on Slavery: Selections from De instauranda Aethiopum salute (Indianapolis, IN: Hackett Publishers, 2006). A pioneering work on Sandoval is Vincent P. Franklin, "Bibliographical Essay: Alonso De Sandoval and the Jesuit Conception of the Negro," Journal of Negro History 58, no. 3 (1973): 349-6o. More recently, see Margaret M. Olsen, Slavery and Salvation in Colonial Cartagena de Indias (Gainesville: University of Florida Press, 2004). Scholarship on Sandoval continues to grow in sophistication. See Larissa Brewer-García, "Hierarchy and Holiness in the Earliest Colonial Black Hagiographies: Alonso de Sandoval and His Sources," William and Mary Quarterly 76, no. 3 (2019), 477-508. 
de Jaguaripe in Brazil in the 158 os illustrates, Jesuit sources (when read carefully and in combination with other sources) can provide fleeting yet valuable glimpses of their worldviews. ${ }^{18}$

The suppression of the Jesuits shattered this slaveholding complex. The Jesuits' property, including their human property, was expropriated and sold off throughout the Americas. Although the inventories of Jesuit holdings have provided scholars with a high-resolution snapshot of the Jesuits' enslaved communities at that moment, their subsequent histories have mostly been lost. When the Jesuits returned to the Americas in the early nineteenth century, the world had changed. Cotton and steam power were on the rise, stoking a "second slavery."19 But the moral and political revolution of antislavery was also underway, punctuated by the overthrow of slavery in St. Domingue and Haitian independence and abolitionism in the Anglo-Atlantic. The Society of Jesus did not rebuild its slaveholding foundations in the Americas, except for-paradoxically —in the United States, where the Jesuit clergy managed to retain a degree of control of their property through the suppression era by entrusting it to a civil corporation. ${ }^{20}$ This tenuous continuity meant that the US Jesuits would have to grapple with the dilemmas of being Catholic slaveholders in a republican, Protestant slave country with a rising antislavery movement.

The (ex-)Jesuits' enterprise in Maryland, with Georgetown as its flagship from the 179os, was intricately tied to slavery. The Jesuits had been supported by slaveowning Catholic tobacco planters and merchants and managed several plantations of their own across Maryland. They routinely bought and sold people, hired them, and hired them out. After long debate, the Jesuits sold nearly all the people they owned to two planters in Louisiana in 1838; the sale got the Jesuits out of an unprofitable business and raised much-needed capital for their operations. But it did not entirely sever the US Jesuits' ties to slavery. Georgetown College itself operated with slave labor from the 179os to the 186os, as Elsa Barraza Mendoza's essay in this issue meticulously documents. And as Kelly Schmidt's essay in this issue also documents, the Jesuits in Missouri,

18 Alida C. Metcalf, "Millenarian Slaves?: The Santidade de Jaguaripe and Slave Resistance in the Americas," American Historical Review 104, no. 5 (1999): 1531-59.

19 Anthony E. Kaye, "The Second Slavery: Modernity in the Nineteenth-Century South and the Atlantic World," Journal of Southern History 75, no. 3 (2009): 627-65.

20 R. Emmett Curran, Shaping American Catholicism: Maryland and New York, 1805-1915 (Washington, DC: Catholic University of America Press, 2012), 31-32. For a sweeping, fresh survey of the Jesuit response to suppression (which neglects the question of slavery), see Paul Shore, "The Years of Jesuit Suppression, 1773-1814: Survival, Setbacks, and Transformation," Brill Research Perspectives in Jesuit Studies 2, no. 1 (2020): 1-117, https://doi. org/10.1163/9789004423374 (accessed June 13, 2020). 
Kentucky, and Louisiana carried the Society's slaveowning practices with them as they moved west. Recovering this history is part of a broader historiographical movement to analyze and understand the relationship between slavery and educational and religious institutions in the nineteenth-century United States, as well as the history of African-American Catholics. ${ }^{21}$

This most recent historiography comes with a renewed focus on the experiences of those held in bondage by the Jesuits, a dedication to the archival recovery of their history, and an attention to the silences in the archives that reflect the power dynamics of slavery. ${ }^{22}$ Building on the rich scholarship of the social history of slavery, the essays in this issue highlight the archival traces of enslaved people in financial ledgers, sacramental registers, and clerical correspondence. These shed light on labor practices, family ties, religious life, the brutality of punishment, and resistance and the aspiration for freedom. It is a one-sided record. In the vast archives of the Society of Jesus, there are precious few documents written by enslaved people or that record their view of the world in their own words. It is telling that perhaps the only document in the Maryland Province Archives written by (or on behalf of) somebody owned by the Jesuits in the United States is Thomas Brown's poignant plea to be allowed to purchase his and his wife Molly's freedom. ${ }^{23}$ Relying on court records, however, the historian William Thomas's new book on freedom suits in the early republic excavates the full story of the Jesuit slaves' extraordinary struggle to win their freedom. ${ }^{24}$

Jesuit and other records dating back to the nineteenth century have enabled genealogists to trace the family histories of the people who were owned and sold by the Society of Jesus and to identify their living descendants, collapsing the

21 An important spark was Craig Steven Wilder, Ebony \& Iry: Race, Slavery, and the Troubled History of America's Universities (New York: Bloomsbury Press, 2013). See also Leslie M. Harris, James T. Campbell, and Alfred L. Brophy, eds., Slavery and the University: History and Legacies (Athens: University of Georgia Press, 2019). The Universities Studying Slavery consortium now has more than sixty member institutions. See https://slavery.virginia.edu/ universities-studying-slavery/ (accessed June 2, 2020). Leading a new wave of scholarship on African-American Catholics are Diane Batts Morrow, Persons of Color and Religious at the Same Time: The Oblate Sisters of Providence, 1828-1860 (Chapel Hill: University of North Carolina Press, 2002); Matthew J. Cressler, Authentically Black and Truly Catholic: The Rise of Black Catholicism in the Great Migration (New York: New York University Press, 2017). Trouillot, Silencing the Past; Marisa J. Fuentes, Dispossessed Lives: Enslaved Woman, Violence, and the Archive (Philadelphia: University of Pennsylvania Press, 2016).

23 Thomas Brown Letter, October 21, 1833, Box 40, Folder 5, Maryland Province Archives, Booth Family Center for Special Collections, Georgetown University, http://slaveryarchive. georgetown.edu/items/show/39 (accessed June 2, 2020). See Kelly Schmidt's essay in this volume for more on Thomas and Molly Brown.

24 William G. Thomas III, A Question of Freedom: The Families Who Challenged Slavery from the Nation's Founding to the Civil War (New Haven, CT: Yale University Press, 2020). 


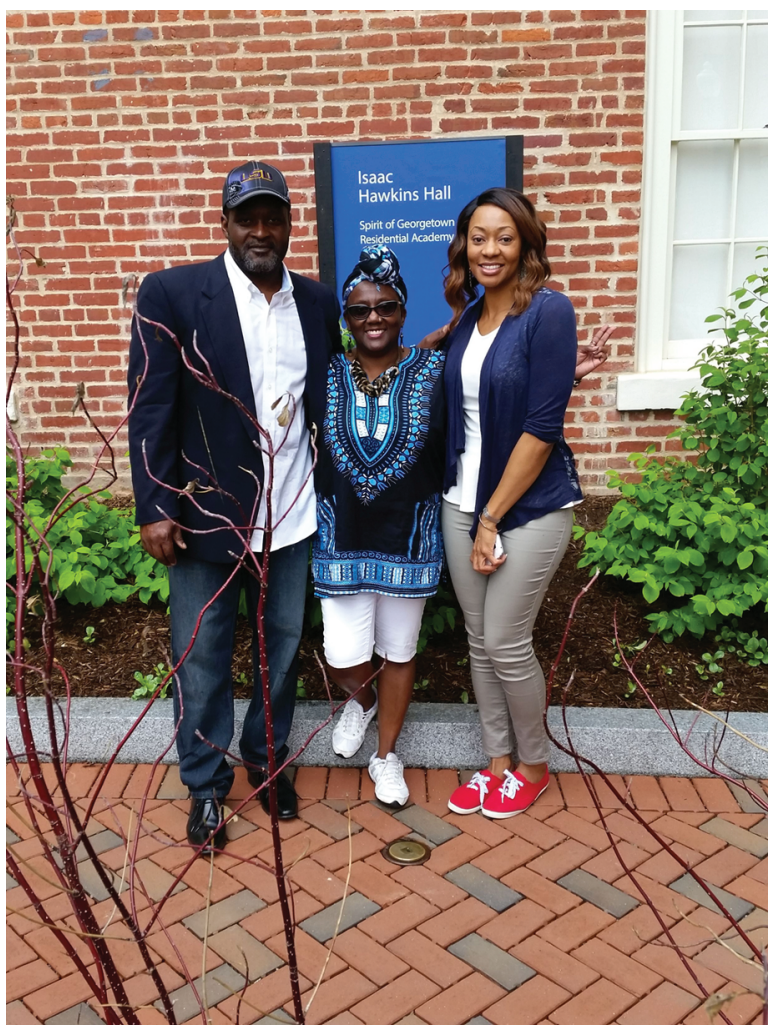

FIGURE 1.2

(From left to right) Carlos Scott, Rochell Sanders Prater, and Helena Dixon standing in front of Isaac Hawkins Hall, Georgetown University, April 18, 2017. Mr. Scott, Ms. Prater, and Ms. Dixon are descendants of Isaac Hawkins.

PHOTOGRAPH TAKEN BY THE AUTHOR

distance between past and present. ${ }^{25}$ Descendant families are welcome to come to Georgetown's Booth Family Center for Special Collections to view the archival materials from the Maryland Province Archives that document their ancestors. This is one way in which the university can honor and tell its own history and learn about theirs, an issue that the contributors note is of great importance to reconciliation as well as a professional and public service. For more information, see http://slavery.georgetown.edu/descendants/. I personally have had the chance to sit and talk with members of the descendant community in the Booth Family Center as together we sift through baptismal records and bills of sale that contain the names of their ancestors. Understanding this history is not an academic exercise for them, and it should not be so for us, either. The process of reconciliation is powerfully informed by history, and it can also improve our historiography. Listening to and learning from the descendants' perspectives, oral histories, and post-slavery experiences will greatly enhance our knowledge of Jesuit slaveholding and its legacies. We have a lot of work to do.

25 Swarns, "Georgetown Confronts Its Role in the Nation's Slave Trade." 